\title{
The Factors That Influence The Customers' Intention To Online Business
}

\author{
Farra Anis Adilla; Farah Diyana; Nur ‘Ain ‘Afifah; Sharina Osman \\ \{farah.kadir02@s.unikl.edu.my, sharina@unikl.edu.my\} \\ Universiti Kuala Lumpur Business School
}

\begin{abstract}
Online business is a platform that the customers use to buy product and services other than brick and mortar. The main purpose of this study is to determine the factors that influence the customers' intention to perform online business. This study employed simple random sampling using questionnaires which were distributed to respondents through online platform. About 103 respondents took part in the survey. Multiple linear regressions have been used to test the differences between independent variable and dependent variable. The result revealed that customer trust and subjective norms are positively and significantly related to customer intention. However, the result shows that website ease of use has a weak but positive relationship with customer intention. On the other hand, website security has no relationship with customer intention.
\end{abstract}

Keyword: Customer's intention, online business, customer characteristic, attributes, website.

\section{Introduction}

According to [1], online business is the process a customer takes to purchase a service or product over the internet. This definition shows that online business is the platform that the customers use to buy product and service other than brick and mortar. The reason of online business is the background of the research is because of the trend of the $21^{\text {st }}$ Century customers that buy through online and the stiff competition between online businesses which lead to know the factors that influence the customers' intention toward online business. However, there are some of the customers still rigid with the offline business which is one of the reason on why this research has been conducted as to know why they still rigid with the offline business. Furthermore, the lack of research about online business in Malaysia is the other push factor to online business has high demand from the customers nowadays because of its convenience and other factors. Website and trust were regarded as the two main factors to influence customer purchase [2] and subjective norm has a direct impact towards the behavioural intention of online users in online shopping [3]. Nowadays, the usage of online business is increasing in Malaysia which impact on the customers' purchase intention. Previous research is focusing on the customers' gender and age difference that influence the customers' intention [4]; [5]; [6]. However, they have not focus on the attribute of the website and the customers' characteristic that influence customers' intention to online shopping. More research needed to be done in order to know which factors between the website's attributes or 
customers' characteristic that has the highest influence to the customers' intention towards online business.

Some latest related studies have conducted by some researchers which showed the similar study to this present study. In a study of [7], they focused on the factors influencing student's buying intention through internet shopping in an institution of higher learning in Malaysia. Several factors such as usefulness, ease of use, compatibility, privacy, security, normativebeliefs and attitude that influence student's buying intention were analyzed. The results of this study showed that the results support seven hypotheses from nine. Compatibility, usefulness, ease of use and security has been found to be important predictors toward attitude in on-line shopping. In addition, [8] also conducted the similar study which aimed to study about factors influencing the intention to buy from online stores. The results of this study have found both TAM constructs and trust constructs to be significant predictors of buying intention, and found also that favorite payment method is not a significant moderator of these relationships. Moreover, [9] have conducted the similar study which focused to analyze the factors that can influence the customers' purchase intention. The results of this study showed that only Utilitarian Value of Internet Information Search, Hedonic Value of Internet Information Search, and Online Purchase Experience are significant predictors of Online Purchase Intention. In addition, the Sobel test showed that Online Search Intention is not a significant mediating variable in this research. Based on the background and the latest related studies above, therefore the purpose of the study is to determine the factors that influence the customers' intention to perform online business which focused to determine the relationship between online shopping's attributes (website security and ease of use) and customers' intention to online business, and to determine the relationship between customers' characteristic (trust and subjective norm) and customers' intention to online business.

\section{Methods}

The study was conducted between July 2019 and August 2019. For this research, quantitative analysis were chosen because the data that be collected are through measuring things. Besides, it is used to determine the correlation between independent and dependent variables. Survey method and primary data were used in this research. The data of this study are collected through survey where distributed the survey questionnaire by online. Google Forms is used which much easier than the traditional interview because it is fast and a simple way to get data from our respondents. For this research purpose, the population are focus on online survey. 103 responded from online survey were randomly selected to participate in the survey to represent the population in this research study. Mostly our responded were in age around 13 until 45 years and above. As mentioned above, questionnaire technique was used for data collection of this study. The questionnaire was adapted from the past literature. This study used five Likert-Scales to identify the respondents' perception that influence the intention on online business. The questionnaire was distributed digitally using Google forms through our teammate's Whatsapps contacts. The data were analyzed after received 103 responds of questionnaire using Statistical Package for the Social Sciences (SPSS). 


\section{Results And Discussion}

\subsection{Respondent Demographic Profile}

This research is focusing on respondents' gender, age and income. These are the variable that will segmenting and classify the respondents that nay have connection and impact between the relationship between the customers' characteristic and customers' intention addition with the relationship between the website characteristic with customers' intention to purchase. The total of the respondent for this research is 104 but only 103 data than can be use. This research has use close ended questions in order to segment the respondent's profile and the responses have been analyse using percentage and frequency distribution which as shown in table 3.1 .

The result show that the respondents are consisted of 68 women with $65.4 \%$ and 36 men with $34.6 \%$. Next is the age of the respondent which there are two group of respondent that has the highest number of respondent which are 13 Years Old until 23 Years Old and 24 Years Old until 34 Years Old with 48 for number of frequency and 46.2\%. The other two group which are 35 Years old until 45 Years Old and Above 46 Years Old have the same lowest number of respondent which is 4 for frequency and $3.8 \%$. Beside is the income of the respondent. The highest number of respondents' income with 35 frequencies and $33.7 \%$ is below RM1000. The second highest number of respondents' income with 29 frequencies and $27.9 \%$ is between RM1001 until RM3000. The third high number of respondents' income is between RM3001 until RM4000 with 6 frequencies and 5.8\%. The lowest number of respondent's income is above RM5000 with 4 frequencies and 3.8\%.

Table 1: Description of Respondent's Demographic profile

\begin{tabular}{clcc}
\hline $\begin{array}{c}\text { Demographic } \\
\text { Variables }\end{array}$ & \multicolumn{1}{c}{ Measure } & $\begin{array}{c}\text { Frequency } \\
\text { (N103) }\end{array}$ & $\begin{array}{c}\text { Percentage } \\
\text { (\%) }\end{array}$ \\
\hline \multirow{3}{*}{ Gender } & Male & 36 & 34.6 \\
& Female & 68 & 65.4 \\
Age & 13 Years Old - 23 Years Old & 48 & 46.2 \\
& 24 Years Old - 34 Years Old & 48 & 46.2 \\
& 35 Years old - 45 Years Old & 4 & 3.8 \\
& Above 46 Years Old & 4 & 3.8 \\
& Below RM1000 & 35 & 33.7 \\
& RM1001 - RM3000 & 29 & 27.9 \\
& RM3001 - RM5000 & 6 & 5.8 \\
& Above RM5001 & 4 & 3.8 \\
& Not all at the above & 30 & 28.8 \\
\hline
\end{tabular}

The objective of this study was set to determine the key factor dimension that influence customer intention to online business in Malaysia. In this study, the factor was measured using 27 quantitative questions in which respondents were required to indicate the extent to which they strongly disagree or strongly agree with each statement by indicating number that best describe their factor and perceptions. All the 25 items on service quality were Likert- Scaled using four points ranging between $1=$ Strongly Disagree, $2=$ Disagree, $3=$ Natural, $4=$ Agree and 5= Strongly Agree. 


\subsection{Reliability test}

The table 2 below show that all the variable is reliable. This variable have been tested to the 103 respondents.

Table 2: Description of Reliability

\begin{tabular}{ccc}
\hline Item & Alpha Value & Interpretation \\
\hline Website Ease of use & 0.902 & Reliable \\
Website Security & 0.904 & Reliable \\
Customer Trust & 0.866 & Reliable \\
Customer Subjective Norms & 0.810 & Reliable \\
Customer Intention & 0.904 & Reliable \\
TOTAL & 0.877 & Reliable \\
\hline
\end{tabular}

\subsection{The Multiple Linear Regression}

Results in table 3.3 indicate that customer trust and customer intention are positively and significant related at $(\mathrm{sig}=0.000)$. Besides that, customer subjective norms and customer intention also positive and significant related at $(\mathrm{sig}=0.000)$. Therefore, hypothesis 3 and hypothesis 4 are supported. However, result in table 3.3 indicate that website ease of use and customer intention are positive and insignificant related at $(\mathrm{sig}=0.745)$. Also, website security and customer intention are negatively and insignificant related at (sig=0.166). Hence, hypothesis 1 and hypothesis 2 are not supported.

Table 3: Description of the coefficient

\begin{tabular}{ccccccc}
\hline & Model & \multicolumn{2}{c}{$\begin{array}{c}\text { Unstandardized } \\
\text { Coefficients }\end{array}$} & $\begin{array}{c}\text { Standardized } \\
\text { Coefficients }\end{array}$ & T & Sig. \\
& B & Std. Error & Beta & & \\
\hline $1 \quad$ (Constant) & 0.326 & 0.342 & & 0.952 & 0.344 \\
& Website Ease of Use & 0.037 & 0.114 & 0.037 & 0.326 & 0.745 \\
& Website Security & -0.168 & 0.121 & -0.167 & -1.395 & 0.166 \\
& Customer Trust & 0.590 & 0.133 & 0.541 & 4.431 & 0.000 \\
$\quad$ Customer & 0.428 & 0.106 & 0.358 & 4.022 & 0.000 \\
& Subjective & & & & & \\
Norms & & & & & \\
& & &
\end{tabular}

a. Dependent Variable: Customer Intention

Table 4: Model Summary

\begin{tabular}{ccccc}
\hline Model & R & R Square & Adjusted R Square & Std. Error of the Estimate \\
\hline 1 & $0.730^{\mathrm{a}}$ & 0.533 & 0.514 & 0.62580 \\
\hline
\end{tabular}

a. Dependent Variable: Customer Intention

b. Predictors: (Constant), Customer Subjective Norms, Website Ease of use, Website Security, Customer Trust

According to table 3.4, the aspects of dependent variable (customer intention) account for $53.3 \%$ variation in the independent variable (Website ease of use, website security, customer trust, customer subjective norms ). The regression test result in table 3.4 shows a $\mathrm{R}$ square is 0.533 and adjusted $\mathrm{R}$ square is 0.514 . The study on the factors that influence the customers' intention to online business was guided by two objectives which are to determine the 
relationship between online shopping's attributes (website security and ease of use) with customers' intention to online business and to determine the relationship between customers' characteristic (trust and subjective norm) with customers' intention to online business. In conclusion, factor that influence customer are trust and subjective norm can influence customer intention. The study variables showed that only trust and subjective norm in factor dimensions are positively and significantly with customer intention. This means in order to get customer trust, the online business need to position the company good image and brand. The online business should consistently update customer feedback, star rating, boost sales and know your customer by knowing your target audience and interacting directly with them. On the other hand, the subjective norm influences the customer intention. Thus, online business should make more e-marketing in order to influence the customers' subjective norm. Example, the company use $\mathrm{Fb}$ ads, review and feedback from customer experiences to make social pressure that might influence customers' intention to purchase the product and service.

\section{Conclusions}

As a conclusion, this study was conducted to determine the factors that influence the customers' intention to online business. Based on the discussion of this survey, customer trust and customer subjective norms are positively and significantly related to customer intention. This shows that customers' characteristic has positive relationship on the customers' intention toward the online business. However, the result of website ease of use has a weak but positive relationship with customer intention. On the other hand, website security has no relationship with customer intention.

\section{References}

[1] Zuroni, "Factors influencing customers' attitude towards e-commerce purchases through online shopping," Int. J. Humanit. Soc. Sci., no. 230, 2012.

[2] Gefen, Karahanna, and Straub, "Trust and TAM in Online Shopping: An Integrated Model," MIS Q., vol. 27, no. 1, p. 51, 2003.

[3] T. H. Lan Ho and Y. Chen, "Vietnamese Consumers' Intention to Use Online Shopping: The Role of Trust," Int. J. Bus. Manag., vol. 9, no. 5, Apr. 2014.

[4] C. Van Slyke, C. Comunale, and F. Belanger, "Gender differences in perceptions of Web-based shopping," Commun. ACM, vol. 45, no. 7, pp. 82-86, 2002.

[5] V. Venkatesh, M. G. Morris, and P. L. Ackerman, "A Longitudinal Field Investigation of Gender Differences in Individual Technology Adoption Decision Making Processes," Organ. Behav. Hum. Decis. Process., vol. 83, no. 1, pp. 33-60, 2000.

[6] I. Spero and M. Stone, "Agents of change: how young consumers are changing the world of marketing," Qual. Mark. Res. An Int. J., vol. 7, no. 2, pp. 153-159, Jun. 2004.

[7] Y. Eri, M. Aminul Islam, and K. A. Ku Daud, "Factors that Influence Customers' Buying Intention on Shopping Online,” Int. J. Mark. Stud., vol. 3, no. 1, 2011.

[8] R. Abu-Shamaa and E. Abu-Shanab, "Factors influencing the intention to buy from online stores: An empirical study in Jordan," Proc. 8th IEEE GCC Conf. Exhib. Muscat, 2015.

[9] J. W. Putri, "Factors Affecting Customers Online Search Intention and Online Purchase Intention using Social Networks : Case Study of Online Shop on Instagram," iBuss Manag., vol. 3, no. 2, pp. 232-240, 2015. 